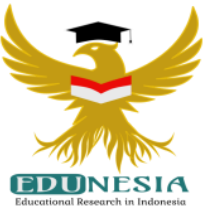

\title{
Kepemimpinan Kepala Sekolah dalam Meningkatkan Kinerja Guru
}

\author{
Bradley Setiyadi'; Viona Rosalina²; \\ ${ }_{12}$ Program Studi Administrasi Pendidikan, Universitas Jambi, Indonesia \\ ${ }^{1}$ Corresponding Email: bradleysetiyadi@unja.ac.id,Phone Number :0812 xxxx xxxx
}

Article History:

Received: Okt 02, 2020

Revised: Okt 13, 2020

Accepted: Okt 15, 2020

Published: Jan 01, 2021

\section{Keywords:}

principal leadership, teacher performance
Kata Kunci:

kinerja guru, kepemimpinan kepala sekolah.

How to cite:

Setiyadi, B., \& Rosalina, V. (2021). Kepemimpinan Kepala Sekolah dalam Meningkatkan Kinerja Guru. Edunesia : Jurnal Ilmiah Pendidikan, 2 (1): 75-84

This is an open access article under the CC-BY-NC-ND licens
Abstract: This study aims to describe the Principal's Leadership in Improving Teacher Performance in SMA Negeri 11 Jambi and the supporting and inhibiting factors of the Principal's Leadership in Improving Teacher Performance in SMA Negeri 11 Jambi. This study used a qualitative descriptive study type case study. The subjects in this study were the Principal and Teachers. Data collection techniques in this study using observation, interviews and document study. Data analysis techniques are data reduction, data presentation and drawing conclusions. Meanwhile, the data validity test used triangulation technique. The results of this study indicate that: (1) Principal's Leadership in Improving Teacher Performance in SMA Negeri 11 Jambi is quite good at coaching teacher performance, monitoring teacher performance, providing motivation and evaluating teacher performance. Meanwhile, teacher performance is also quite good in preparing lesson plans, managing learning activities, and conducting learning evaluations. (2) The supporting factor is strong support and motivation from the principal. The inhibiting factors are the lack of LCD projector and internet network, the lack of the ability of teachers to manage classrooms and use various learning methods and the lack of teacher discipline. Based on the research results it is recommended that the principal make improvements and affirmation to the teacher so that the principal leadership process in improving teacher performance can then be carried out optimally.

Abstrak: Penelitian ini bertujuan untuk mendeskripsikan tentang Kepemimpinan Kepala Sekolah dalam Meningkatkan Kinerja Guru di SMA Negeri 11 Kota Jambi dan Faktor pendukung dan penghambat Kepemimpinan Kepala sekolah dalam Meningkatkan Kinerja Guru di SMANegeri 11 Kota Jambi. Penelitian ini menggunakan deskriptif kualitatif dengan jenis penelitian studi kasus. Subjek dalam penelitian ini adalah Kepala Sekolah dan Guru. Teknik pengumpulan data dalam penelitian ini menggunakan observasi, wawancara dan studi dokumen. Teknik analisis data yaitu dengan reduksi data, penyajian data dan penarikankesimpulan. Sedangkan uji keabsahan data menggunakan teknik triangulasi. Hasil penelitian ini menunjukan bahwa: (1) Kepemimpinan Kepala Sekolah dalam Meningkatkan Kinerja Guru di SMA Negeri 11 Kota Jambi cukup baik dalam melakukan pembinaan kinerja guru, pengawasan kinerja guru, pemberian motivasi serta evaluasi terhadap kinerja guru. Sedangkan untuk kinerja guru juga cukup baik dalam menyusun rencana pembelajaran, mengelola kegiatan pembelajaran, dan melakukan evaluasi pembelajaran. (2) Faktor pendukungnya ialah adanya dukungan serta motivasi yang kuat dari kepala sekolah. Faktor penghambatnyaialah kurangnya proyektor LCD dan jaringan internet, kurangnya kemampuan guru dalam mengelola kelas dan menggunakan berbagai metode pembelajaranserta kurangnya kedisiplin guru. Berdasarkan hasil penelitian direkomendasikan agar kepala sekolah melakukan perbaikan dan penegasan kepada guru agar proses kepemimpinan kepala sekolah dalam meningkatkan kinerja guru selanjutnya dapat dilaksanakan dengan maksimal. 


\section{A. Pendahuluan}

Ketercapaian tujuan pendidikan sangat tergantung pada kecakapan dan kebijaksanaan kepala sekolah sebagai pemimpin. Kepala sekolah merupakan kunci bagi pengembangan dan peningkatan kualitas bagi suatu sekolah karena fungsinya sebagai pemimpin sangat berpengaruh bagi keberlangsungan proses belajar mengajar. Oleh karena itu diperlukan sosok kepala sekolah yang tangguh dan memiliki kompetensi yang mendukung tugasnya dalam proses pendidikan (Kompri, 2017). Kepemimpinan kepala sekolah adalah upaya yang dilakukan kepala sekolah sebagai leader memengaruhi banyak orang (guru, tenaga administrasi, siswa, stakeholders) melalui komunikasi untuk mencapai tujuan sekolah. Indikatornya adalah kepala sekolah mampu menggerakkan semua warga sekolah untuk melaksanakan tugas dan tanggung jawab sesuai dengan tugas dan tanggung jawab yang diberikan. Dari sini dapat dipahami bahwa kepemimpinan kepala sekolah adalah kemampuan para pimpinan sekolah untuk mempengaruhi, membimbing, dan mengarahkan guru pegawai, siswa, dan segenap warga (stakeholder) sekolah untuk mencapai tujuan sekolah.

Kepemimpinan kepala sekolah yang baik harus dapat mengupayakan peningkatan kinerja guru, karena kinerja guru juga merupakan penentu tinggi rendahnya kualitas pendidikan. Oleh karena itu, kepala sekolah mempunyai tanggung jawab besar dalam organisasi pendidikan dan untuk memimpin organisasinya agar bisa berjalan dengan baik. Peran kepala sekolah yaitu sebagai educator, manajer, administrator, supervisor, leader, innovator, motivator (EMASLIM) (Mulyasa, 2013). Keterlaksanaan pembelajaran yang baik tidak terlepas dari peran kepala sekolah selaku manajer dalam instansi sekolah. Kepala sekolah harus dapat menuntun warga sekolah untuk mencapai tujuan sesuai dengan visi dan misi yang telah ditetapkan. Kepala sekolah harus mampu memberikan motivasi terhadap warga sekolah. Oleh karena itu, kepala sekolah harus mengenal lebih dekat kepada setiap warga sekolah agar lebih mudah dalam melaksanakan tugasnya dengan baik misalnya melalui komunikasi interpersonal. Membangun komunikasi interpersonal yang baik, menciptakan suasana kerja yang nyaman merupakan salah satu cara agar lebih mudah dalam pencapaian tujuan. Dengan demikian, kepala sekolah berperan penting dalam meningkatkan kinerja guru dalam melaksanakan tugas dan kewajibannya. Menurut Supardi (2013) kinerja guru adalah suatu kondisi yang menunjukkan kemampuan seorang guru dalam menjalankan tugasnya di sekolah serta menggambarkan adanya suatu perbuatan yang ditampilkan guru selama melakukan aktivitas pembelajaran.

Berdasarkan observasi awal di lapangan, permasalahan yang ditemukan oleh peneliti yaitu upaya kepala sekolah dalam meningkatkan kinerja guru belum sepenuhnya dilakukan secara maksimal.Contohnya, masih ditemukan guru yang datang terlambat ke sekolah dan ketika sudah masuk jam pelajaran diaman masih ditemukan guru yang tidak langsung masuk ke ruang kelas. Seharusnya guru harus datang lebih awal dari siswa agar dapat memberikan contoh yang baik untuk siswa. Permasalahan lain dapat dilihat dari segi guru dalam mempersiapkan perencanaan pembelajaran dimana masih ditemukan ada guru yang belum sepenuhnya mempersiapkan semua kebutuhan administrasi tersebut. Sementara itu, dalam pelaksanaan pembelajaran dimana guru masih belum mampu menggunakan berbagai metode serta memilih metode pembelajaran yang tepat dan sesuai dalam proses pembelajaran, dan juga guru masih kurang dalam mengelola kelas. Kemudian dilihat dari evaluasi pembelajaran dimana masih ada guru yang tidak melakukan penilaian terhadap hasil belajar dan tidak memberikan refleksi terhadap kegiatan yang sudah 
dilaksanakan serta tidak melakukan tindak lanjut dalam bentuk pembelajaran remedi dan program pengayaan.

Berdasarkan uraian permasalahan yang telah dikemukaan, maka peneliti tertarik untuk mengkaji upaya yang dilakukan kepala sekolah dalam meningkatkan kinerja guru disekolah. Tujuan penelitian ini yaitu untuk mendeskripsikan kepemimpinan kepala sekolah dalam meningkatkan kinerja guru di SMA Negeri 11 Kota Jambi dan untuk mengetahui faktor pendukung dan faktor penghambat kepemimpinan kepala sekolah dalam meningkatkan kinerja guru di SMA Negeri 11 Kota Jambi.

\section{B. Metode}

Pendekatan yang digunakan dalam penelitian ini yaitu menggunakan pendekatan deskriptif kualitatif dengan jenis penelitian studi kasus (case study). Metode kualitatif merupakan metode-metode untuk mengeksprorasi dan memahami makna yang oleh sejumlah individu atau sekelompok orang di anggap berasal dari masalah sosial atau kemanusiaan. Sementara studi kasus merupakan strategi penelitian dimana didalamnya peneliti menyelidiki secara cermat suatu program, peristiwa, aktivitas, proses, atau sekelompok individu. Kasus-kasus dibatasi oleh waktu dan aktivitas, dan peneliti mengumpulkan informasi secara lengkap dengan menggunakan berbagai prosedur pengumpulan data berdasarkan waktu yang telah ditentukan (Creswell, 2013). Studi kasus ini bertujuan untuk mengungkapkan kejadian atau fakta, keadaan, fenomena, variabel dan keadaan yang terjadi saat penelitian berlangsung dengan menyuguhkan apa yang sebenarnya terjadi.

Subjek dalam penelitian ini ialah kepala sekolah dan 5 (lima) orang guru yang disebut dengan istilah partisipan. Partisipan dalam penelitian ini dipilih secara "Purpose Sampling". Purpose sampling adalah teknik untuk menentukan sampel penelitian dengan beberapa pertimbangan tertentu, misalnya orang tersebut dianggap paling tahu tentang apa yang kita harapkan yang bertujuan agar data yang diperoleh nantinya lebih representatif (Sugiyono, 2014).

Sumber data yang digunakan terdiri atas data primer dan data sekunder. Data primer, yaitu data yang diperoleh secara langsung dari informan di lapangan yaitu melalui observasi dan wawancara mendalam dengan kepala sekolah dan beberapa guru mengenai kepemimpinan kepala sekolah dalam meningkatkan kinerja guru SMA Negeri 11 Kota Jambi. Sedangkan data sekunder, yaitu data yang diambil dari dokumen tertulis yang diperoleh dari pihak SMA Negeri 11 Kota Jambi seperti buku-buku, foto, dokumen tentang profil sekolah, struktur organisasi, daftar pendidik dan tenaga kependidikan, jumlah peserta didik, rombongan belajar, sarana dan prasarana, serta jadwal pembelajaran guru yang mengajar, dan lain-lain. Serta data dari artikel yang diperoleh dari website yang berhubungan dengan penelitian ini.

Teknik pengumpulan data yang digunakan dalam penelitian ini adalah observasi, wawancara dan studi dokumen. Observasi dalam penelitian ini digunakan untuk memperoleh data mengenai kepemimpinan kepala sekolah dalam meningkatkan kinerja guru. Tujuannya untuk mengetahui bagaimana kepemimpinan dari kepala sekolah tersebut. Sementara wawancara yang digunakan adalah wawancara terstruktur dan terbuka. Wawancara ini terfokus pada Kepemimpinan Kepala Sekolah dalam Meningkatkan Kinerja Guru di SMA Negeri 11 Kota Jambi. Sedangkan studi dokumen dimaksudkan untuk mengumpulkan data yang berkaitan dengan kinerja guru dalam proses 
pembelajaran, daftar siswa, tata tertib sekolah, absen kehadiran siswa, data nilai siswa, dan dokumen-dokumen yang dianggap memiliki relevansi terhadap data yang diperlukan. Teknik pemeriksaan keabsahan data yang digunakan dalam penelitian ini adalah teknik Triangulasi. Teknik triangulasi yang dilakukan adalah sebagai berikut: (1) Melakukan triangulasi waktu yaitu seminggu setelah melakukan wawancara. Triangulasi waktu dilakukan dengan tujuan untuk mencari kesesuaian data yang bersumber dari dua masalah yang setara pada waktu yang berbeda. Hasil wawancara dikaji berdasarkan indikator Kinerja Guru. Dengan cara demikian diharapkan keseluruhan data saling menguatkan dan memberikan pemahaman yang lebih mendalam mengenai peran kepala sekolah dalam meningkatkan kinerja guruMembuat catatan setiap tahapan penelitian dan dokumentasi yang lengkap; (2) Melakukan pentranskripan segera setelahmelakukan pengambilan data. Hal ini dilakukan agar unsur-unsur subyektifitas peneliti tidak ikut mengintervensi data penelitian; (3) Melakukan pengecekan berulang kali terhadap rekaman suara, instrumen penelitian dan trankrip wawancara agar diperoleh hasil yang sahih; dan (4) Peneliti menanyakan kembali hasil rekaman saat wawancara kepada kepala sekolah dan gurubahwa pernyataan dari kepala sekolah dan guru tersebut sudah benar.selanjutnya pernyataan kepala sekolah dikonfirmasi juga dengan guru apa sesuai dengan yang disampaikan kepala sekolah, begitupun pernyataan guru juga dipertanyakan dengan kepala sekolah sehinggadata yang didapat peneliti dari kepala sekolah dan guru diperoleh data yang sahih. Teknik analisis data yang digunakan dalam penelitian ini Analisis data wawancara (kualitatif) dalam penelitian ini dianalisis dengan menggunakan teknis analisis yang yang meliputi (1) reduksi data, (2) penyajian data, (3) penarikan kesimpulan dan verifikasi.

\section{Hasil dan Pembahasan Deskripsi Temuan}

Dari data hasil wawancara penelitian bersama dengan 6 orang partisipan, penelitian ini menunjukan bahwa terdapat berbagai hal penting yang berkaitan dengan Kepemimpinan Kepala Sekolah dalam meningkatkan kinerja guru di SMA Negeri 11 Kota Jambi. Agar dapat mempermudah mendeskripsikan hasil penelitian ini, maka peneliti membaginya ke dalam beberapa tema dan sub tema dalam penelitian ini yang berkaitan erat dengan judul penelitian, sehingga dapat menjawab pertanyaan penelitian sebagaimana diuraikan dalam Tabel 1 di bawah ini :

Tabel 1

Tema dan sub tema penelitian

\begin{tabular}{lllr}
\hline No & \multicolumn{1}{c}{ Tema } & \multicolumn{3}{c}{ Sub Tema } \\
\hline 1. & $\begin{array}{l}\text { Kepemimpinan Kepala } \\
\text { Sekolah dalam } \\
\text { meningkatkan kinerja } \\
\text { guru }\end{array}$ & $\begin{array}{l}\text { Pembinaan Kinerja guru dengan } \\
\text { mengikutsertakan guru dalam pelatihan dan } \\
\text { pembinaan disiplin }\end{array}$ \\
\hline & $\begin{array}{l}\text { Pengawasan terhadap kinerja guru dengan } \\
\text { melakukan observasi tiap kelas dan pengawasan } \\
\text { terhadap kinerja guru dalam kegiatan } \\
\text { pembelajaran }\end{array}$
\end{tabular}




\begin{tabular}{|c|c|c|}
\hline No & Tema & Sub Tema \\
\hline & & $\begin{array}{l}\text { Pemberian motivasi kepada guru dalam bentuk } \\
\text { masukan/dorongan dan menciptakan hubungan } \\
\text { kerja yang harmonisserta memberikan } \\
\text { penghargaan. }\end{array}$ \\
\hline & & $\begin{array}{l}\text { Melakukan evaluasi terhadap kinerja guru } \\
\text { dengan mengadakan rapat dan melakukan } \\
\text { evaluasi secara kontinyu untuk peningkatan } \\
\text { kinerja guru }\end{array}$ \\
\hline 2. & $\begin{array}{l}\text { Faktor-faktor } \\
\text { meningkatkan } \\
\text { guru }\end{array}$ & $\begin{array}{l}\text { Faktor Pendukung dan } \quad \text { Penghambat } \\
\text { Kepemimpinan kepala sekolah meningkatkan } \\
\text { kinerja guru }\end{array}$ \\
\hline
\end{tabular}

Untuk mengetahui Kepemimpinan Kepala Sekolah dalam Meningkatkan Kinerja Guru di SMA Negeri 11 Kota Jambi dan apa saja faktor pendukung dan penghambat dalam pelaksanaannya. berikuthasil penelitian yang penulis lakukan melalui wawancara, observasi, dan dokumentasi kepada kepala sekolah.

\section{Kepemimpinan Kepala Sekolah dalam Membina Kinerja Guru}

Hasil penelitian berdasarkan wawancara dan observasi menunjukkan bahwa kepala sekolah telah melakukan kegiatan pembinaan guru dalam bentuk mengkiutsertakan guru dalam pelatihan atau seminar dan mendorong guru untuk melanjutkan pendidikan yang lebih tinggi. Hal ini belum sepenuhnya terlaksana secara maksimal karena program pelatihan hanya diikutsertan dalam kegiatan di luar sekolah saja dan hanya baru beberapa guru yang diikutkan sesuai utusan dari dinas. Sedangkan untuk mengadakan seminar atau pelatihan dan lainnya di sekolah sendiri itu belum dilaksanaan karena masih direncanakan dengan menghadiri narasumber dari luar.

Hal ini sejalan dengan pendapat Gaol (2018) upaya yang dapat dilakukan oleh kepala sekolah untuk meningkatkan kinerja guru adalah dengan mengarahkan guru supaya mengikuti kegiatan pendidikan dan pelatihan untuk memperbaiki kompetensinya, misalnya, mengikuti seminar atau workshop. Hal yang senada juga disampaikan oleh Muspawi, dkk (2020) bahwa upaya kepala sekolah untuk peningkatan kompetensi profesional guru yaitu dengan cara melaksanakan proses pembinaan dan melibatkan guru dalam berbagai kegiatan pendidikan dan latihan, seminar, workshop, maupun Kelompok Kerja Guru.

Kepala sekolah juga telah melakukan pembinaan disiplin dengan menunjukan sikap keteladanan yaitu dengan datang tepat waktu dan berpakaian rapi serta menggunakan waktu belajar secara efektif. Untuk pembinaan disiplin ini kepala sekolah selalu mengecek kehadiran guru. Jika ditemui ada guru yang tidak disiplin maka akan ada teguran dari kepala sekolah. Namun berdasarkan hasil wawancara dengan kepala sekolah diperoleh informasi bahwa masih terdapat guru yang terlambat datang ke sekolah dan ketika masuk jam pelajaran guru tidak langsung masuk ke kelas.

Dalam pembinaan disiplin yang dilakukan kepala sekolah masih belum dilaksanakan secara maksimal dikarenakan masih kurangnya ketegasan kepala sekolah dalam membina kedisiplinan guru, namun untuk sikap keteladanannya telah ditunjukan 
oleh kepala sekolah. Pembinaan disiplin itu sangat penting untuk meningkatkan kinerja guru, sejalan dengan pendapat Istikhomah (2018) yang menyatakan bahwa seorang pemimpin harus mampu menumbuhkan disiplin, terutama disiplin diri (self-discipline). Dalam kaitan ini, pemimpin harus mampu membantu pegawai mengembangkan pola dan meningkatkan standar perilakunya, serta menggunakan pelaksanaan aturan sebagai alat untuk menegakkan disiplin. Disiplin merupakan sesuatu yang penting untuk menanamkan rasa hormat terhadap kewenangan, menanamkan kerjasama, dan merupakan kebutuhan rasa hormat terhadap orang lain.

\section{Kepemimpinan Kepala Sekolah dalam Pengawasan terhadap Kinerja Guru}

Tugas kepala sekolah dalam mengawasi kinerja guru memang sudah dilaksanakan, namun belum sepenuhnya maksimal. Hal ini akan berimplikasi terhadap peningkatan kinerja guru di sekolah tersebut karena akan terjadi naik turunnya kinerja guru dan itu berpengaruh pada proses pembelajaran terhadap siswa. Berdasarkan hasil wawancara dan observasi menunjukan bahwa kepala sekolah telah melakukan pengawasan terhadap kinerja guru dengan observasi/controlling kelas dan kunjungan ke kelas untuk melihat secara langsung proses pembelajaran yang dilakukan guru. Namun untuk observasi/controlling ke tiap-tiap kelas itu sering dilakukan jika kepala sekolah stanby di sekolah namun jika kepala sekolah sedang ada dinas atau ada keperluan di luar peneliti melihat permasalahan guru tersebut dipecahkan sendiri. Untuk pengawasan kinerja guru saat kegiatan belajar di dalam kelas itu tidak rutin dilakukan karena itu ada jadwaljadwalnya. Jika ditemukan kendala atau kesulitan guru dalam mengajar maka kepala sekolah memberikan solusi atau tindak lanjut atas permasalahan yang di alami guru.

Hal ini sejalan dengan teori Setiyadi (2020) bahwa mengobservasi kelas merupakan satu teknik supervisi individu yang dilaksanakan oleh kepala sekolah atau pengawas untuk mengawasi dan memperhatikan proses belajar mengajar berlangsung. Hasil penelitian yang dilakukan peneliti sejalan dengan penelitian yang dilakukan Abdillah (2018) yang menyatakan bahwa kepala sekolah melakukan kunjungan ke kelas saat proses pembelajaran berlangsung untuk melihat dan menilai bagaimana kinerja guru serta selalu membimbing dan mengarahkan guru dalam menjalankan tugasnya. Hal ini selagi kepala sekolah berada disekolah tapi jika kepala sekolah sedang ada urusan diluar, maka guru pecahkan masalahnya sendiri dan dibantu para guru lainnya.

\section{Kepemimpinan Kepala Sekolah dalam Memberikan Motivasi Kepada Guru}

Berdasarkan hasil wawancara dan observasi menunjukan bahwa kepala sekolah telah memberikan motivasi kepada guru, adapun motivasi yang diberikan oleh kepala sekolah yaitu dengan memberikan dorongan dan masukan kepada guru dan menciptakan hubungan yang harmonis serta suasana kerja yang menyenangkan agar guru dapat meningkatkan kinerjanya. Hal ini dilakukan kepala sekolah saat rapat maupun diskusi secara individu dengan guru. Selain itu juga dengan memberikan penghargaan baik berupa kenaikan pangkat atau jabatan, uang atau barang, piagam/sertifikat. Namun untuk pemberian penghargaan tersebut jarang dilakukan dikarenakan anggaran yang terbatas. Adapun bentuk penghargaan yang biasanya diberikan oleh kepala sekolah kepada guru yaitu berupa pujian atau pengakuan serta apresiasi atau ucapan terimakasih terhadap guru yang yang kinerjanya bagus. 
Hal ini sejalan dengan teori Musbikin (2013) mengatakan bahwa kepala sekolah harus memiliki strategi yang tepat untuk memberikan motivasi kepada tenaga kependidikan dalam melakukan berbagai tugas dan fungsinya. Motivasi ini dapat tumbuh melalui pengaturan fisik, pengaturan suasana kerja, disiplin, dorongan, penghargaan secara efektif dan penyediaan berbagai sumber belajar mengajar pengembangan pusat sumber belajar.

\section{Kepemimpinan Kepala Sekolah dalam Melakukan Evaluasi terhadap Kinerja Guru}

Berdasarkan hasil wawancara dapat disimpulkan bahwa kepala sekolah telah melakukan evaluasi kinerja guru dengan melakukan rapat walaupun hanya akhir tahun ajaran. Hal ini bertujuan untuk mengetahui seberapa baik kinerja guru dan keberhasilan siswa dalam kegiatan pembelajaran serta mengetahui seluruh komponen semua kelebihan dan kelemahan guru dalam menjalankan tugasnya, khusus untuk kelemahannya setelah proses evaluasi bersama nantinya akan dibenahi bersama dan kepala memberikan tindak lanjut terhadap kelemahan tersebut. Setelah itu dilakukan evaluasi secara kontinyu artinya melihat sampai dimana kemajuan atau kekurangan dalam proses yang diamati. Dengan demikian penulis menyimpulkan kepala sekolah telah melaksanakan evaluasi kinerja guru walaupun belum maksimal.

\section{Faktor Pendukung}

Dari hasil wawancara, observasi dan studi dokumen menunjukan bahwa terdapat beberapa faktor pendukung kepala sekolah dalam meningkatkan kinerja guru yaitu dengan memberikan dorongan dan dukungan kepada guru agar melanjutkan pendidikan lebih tinggi dan antusiaspara guru yang selalumaudi ikutsertakandalampelatihan-pelatihanbaik di sekolahmaupun di luar sekolah sehingga dapat meningkatkan kualitasnya dalam mengajar. Selanjutnya, terpenuhinya sarana dan prasarana yang ada di sekolah, karena sarana dan prasarana itu merupakan penunjang berhasilnya KBM (Kegiatan Belajar Mengajar). Kemudian, setiap guru harus mampu memberikan variasi dalam metode pembelajaran agar siswa tidak merasa bosan selama proses pembelajaran. Selain itu, adanya motivasi yang kuat dari kepala sekolah dan memberikan penghargaan kepada guru yang telah melakukan kinerjanya dengan baik.

\section{Faktor Penghambat}

Dari hasil wawancara, observasi dan studi dokumen menunjukan bahwa terdapat faktor penghambat kepala sekolah dalam meningkatkan kinerja guru yaitu masih ada guru yang berstatus honorer, sehingga hal tersebut bisa berkaitan dengan kinerja dari seorang guru. Kemudian sarananya masih kurang seperti proyektor LCD sehingga terhambatnya dalam proses pembelajaran. Kurangnya kemampuan dari guru dalam mengelola kelas dan menciptakan iklim belajar yang kondusif dan menenyenagkan sehingga siswa merasa bosan dalam belajar. Selanjutnya masih terdapat guru yang belum sepenuhnya disiplin seperti datang kesekolah dan masuk kelas. Hal ini akan membuat siswanya ribut dan sering keluar-keluar kelas sehingga mengganggu kelas lain yang sedang belajar. 


\section{Kesimpulan dan Saran Kesimpulan}

Berdasarkan hasil penelitian dan pembahasan Kepemimpinan Kepala sekolah dalam Meningkatkan Kinerja Guru di SMA Negeri 11 Kota Jambi baik melalui wawancara, observasi, dan dokumentasi, maka dapat disimpulkan:

1. Kepemimpinan kepala sekolah dalam meningkatkan kinerja guru di SMA Negeri 11 Kota Jambi cukup baik namun belum maksimal. Hal ini dibuktikan dengan penjelasan di bawah ini:

a. Pembinaan kinerja guru, dalam pembinaan kinerja guru kepala sekolah telah melakukan pembinaan pengembangan profesi guru yaitu dengan mengikutsertakan guru-guru dalam kegiatan seminar, diklat, dan pelatihan hanya saja pelatihan yang diikuti guru-guru masih program dari pemerintah dan baru beberapa guru yang diikutkan dalam bentuk pelatihan tersebut. Selain itu kepala sekolah juga membiasakan disiplin waktu kepada guru.

a. Pengawasan terhadap kinerja guru, dalam melakukan pengawasan terhadap kinerja guru, kepala sekolah sudah melakukan observasi ke tiap-tiap kelas atau controlling melihat kondisi kelas. Kemudian untuk pengawasan saat kegiatan pembelajaran dikelas itu belum terlaksana secara maksimal. Dikarenakan untuk melakukan kunjungan kelas saat proses belajar berlangsung itu tidak rutin dilakukan dilakukan berdasarkan jadwal-jadwalnya.Pemberian motivasi kepada guru, kepala sekolah juga sudah memberikan motivasi dengan cukup baik, motivasi diberikan secara pribadi maupun saat rapat kepada guru-guru untuk memberikan semangat kepada para guru dan memberikan dorongan kepada guru untuk meningkatkan kinerjanya.

b. Melakukan evaluasi terhadap kinerja guru, evaluasi kegiatan belajar dan kinerja guru dilakukan kepala sekolah setiap akhir tahun ajaran untuk mengetahui seberapa besar keberhasilan siswa dalam menerima pelajaran dan mengetahui apakah kinerja guru semakin baik dalam melaksanakan tugasnya.

c. Adapun mengenai indikator kinerja guru dalam merencakan pembelajaran, mengelola pelasanaan dan mengevaluasi pembelajaran sudah dilaksanakan cukup baik oleh guru namun masih belum maksimal karena masihada guru tidak membuat RPP, kemudian juga dalam pelaksanaannya masih terdapat guru yang belum menggunakan metode yang bervariasi, selanjutnya untuk evaluasi juga masih ada guru yang tidak memberikan penilaian dan menindaklanjuti hasil penilaian.

2. Faktor pendukung dan penghambat kepemimpinan kepala sekolah dalam meningkatkan kinerja guru di SMA Negeri 11 Kota Jambi. Adapun faktor pendukung yaitu dengan memberikan dukungan kepada setiap guru untuk melanjutkan pendidikan yang lebih tinggi, terpenuhinya sarana dan prasarana yang lengkap disekolah, guru juga harus menggunakan metode yang bervariasi, serta adanya motivasi yang kuat dari kepala sekolah dan selalu memberikan penghargaan kepada setiap guru yang kinerjanya bagus. Adapun faktor penghambatnya yaitu kepala sekolah belum sepenuhnya mengikutsertakan guru-guru dalam pelatihan, diklat, atau seminar, guru yang belum beruntung untuk menjadi PNS yang masih berstatus honorer tentunya belum bisa secara optimal untuk menjalankan kinerjanya, proyektor LCD yang masih kurang dan jaringan internet yang belum memadai, kurangnya kemampuan guru dalam mengelola kelas dan 
menciptakan iklim belajar yang kondusif dan menyenangkan, dan kurangnya kedisiplinan guru.

\section{Saran}

Berdasarkan beberapa kesimpulan yang telah dipaparkan, beberapa poin saran yang peneliti sampaikan adalah sebagai berikut:

1. Kepala sekolah hendaknya lebih tegas dalam keputusan yang berkaitan dengan peraturan disekolah dan kepala sekolah juga harus lebih menegaskan kedisiplinan kepada seluruh warga sekolah serta hubungan yang harmonis dengan warga sekolah dan harus melaksanakan tugasnya dengan penuh tanggung jawab agar dapat lebih mengoptimalkan dalam upaya peningkatan kinerja guru di SMA Negeri 11 Kota Jambi, berikut saran untuk kepala sekolah dalam:

a. Pembinaan kinerja guru, kepala sekolah sebaiknya meneruskan kegiatan yang sudah dilakukan oleh kepala sekolah sebelumnya yaitu dengan mengadakan pelatihan, seminar, atau diklat yang diadakan di sekolah. Dengan harapan semakin banyaknya guru yang mendapatkan pelatihan maka semakin baik juga kinerja guruguru yang ada di SMA Negeri 11 Kota Jambi

b. Pengawasan terhadap kinerja guru, Seharusnya kepala sekolah lebih sering melakukan kunjungan ke kelas-kelas agar kinerja guru tetap terpantau dengan baik, tidak hanya sekedar lewat-lewat di depan kelas atau melihat kondisi kelas dari luar

c. Pemberian motivasi kepada guru, dalam memberikan motivasi kepala sekolah sudah cukup baik dengan cara berkomunikasi yang tidak menegangkan, sebaiknya kepala sekolah selalu konsisten dan adanya ketegasan lagi dalam memberikan motivasi agar guru lebih semangat dan disiplin.

d. Evaluasi terhadap kinerja guru, sebaiknya evaluasi dilakukan tidak hanya persemester tapi minimal 1 semester itu dilakukan 2 kali agar dapat lebih maksimal mengetahui bagaimana hasil pembelajaran yang telah dilakukan oleh guru.

e. Kepala sekolah dalam meningkatkan kinerja guru sebaiknya kepala sekolah juga lebih tanggap dalam menghadapi kendala-kendala dan permasalahan dalam kinerja guru dalam merencanakan, melaksanakan dan evaluasi pembelajaran dan harapanya kepala sekolah dapat melakukan program-program dengan konsisten guna kepentingan lembaga.

f. Untuk mengatasi faktor penghambat kepala sekolah dalam meningkatkan kinerja guru SMA Negeri 11 Kota Jambi maka diharapkan kesatuan langkah dan kebersamaan tujuan semua komponen sekolah baik kepala sekolah, guru, siswa dan orang tua serta masyarakat sekitar untuk bersama-sama melakukan visi dan misi sekolah.

2. Kepada guru sebagai bagian dari satuan pendidikan agar lebih aktif dan meningkatkan kesadaran akan pentingnya peran guru sebagai salah satu penentu keberhasilan suatu proses pembelajaran serta memperhatikan dan mentaati tata tertib disekolah.

3. Untuk penelitian selanjutnya dapat dikembangkan topik mengenai kepemimpinan kepala sekolah dalam aspek yang lain yang berkaitan dengan kompetensi kepala sekolah sebagai pemimpin organisasi pendidikan. 


\section{Daftar Pustaka}

Abdillah, M.H. (2018). Pengembangan Budaya Sekolah di Madrasah Ibtidaiyah Negeri Buduran Sidoarjo. Halaqo: Islamic Education Journal, Vol. 2 No. 1, 74-86.

Creswel, J. W (2013). Research Design Pendekatan Kualitatif, Kuantitatif dan Mixed. Pustaka Pelajar: Yogyakarta.

Gaol, N. T. L., \& Siburian, P. (2018). Peran Kepala Sekolah Dalam Meningkatkan Kinerja Guru. Kelola: Jurnal Manajemen Pendidikan, Vol. 5, No.1, 66-73.

Istikhomah. (2018). Strategi kepemimpinan dalam meningkatkan kinerja guru. Jurnal Nur El-Islam, Vol. 13, No. 2.

Kompri. (2017). Standarisasi Kompetensi Kepala Sekolah: Pendekatan Teori untuk Praktek Profesional. Jakarta: Kencana Prenada Media Group.

Mulyasa, H. E. (2013). Menjadi Kepala Sekolah Profesional. Bandung: Remaja Rosdakarya.

Musbikin, I. (2013). Menjadi Kepala Sekolah Yang Hebat. Pekanbaru: Zanafa.

Muspawi, M., B. Setiyadi., \& Gunawan, G. (2020). Upaya Kepala Sekolah Untuk Peningkatan Kompetensi Profesional Guru. Jurnal Ilmiah Universitas Batanghari Jambi, Vol. 20, No. 1. Hal. 95-103

Setiyadi, B. (2020). Supervisi dalam Pendidikan. Purwodadi: Sarnu Untung.

Sugiyono. (2014). Metode Penelitian Pendidikan Pendekatan Kuantitatif, Kualitatif, dan RED. Bandung: Alfabeta.

Supardi. (2013). Kinerja Guru. Jakarta: Rajawali Pers. 